九州大学学術情報リポジトリ

Kyushu University Institutional Repository

\title{
The Effect of Technological Innovation on
} Environmental Quality: Accounting Ecological Footprint Indicators for Asian Countries

Hosan, Shahadat

International Institute for Carbon-Neutral Energy Research (WPI-I2CNER), Kyushu University

Md. Matiar Rahman

International Institute for Carbon-Neutral Energy Research (WPI-I2CNER), Kyushu University

Shamal Chandra Karmaker

International Institute for Carbon-Neutral Energy Research (WPI-I2CNER), Kyushu University

Bidyut Baran Saha

International Institute for Carbon-Neutral Energy Research (WPI-I2CNER), Kyushu University

https://doi.org/10.5109/4102488

出版情報: Proceedings of International Exchange and Innovation Conference on Engineering \& Sciences (IEICES). 6, pp. 198-203, 2020-10-22. Interdisciplinary Graduate School of Engineering Sciences, Kyushu University バージョン：

権利関係: 


\title{
The Effect of Technological Innovation on Environmental Quality: Accounting Ecological Footprint Indicators for Asian Countries
}

\author{
Shahadat Hosan ${ }^{1,2}$, Md. Matiar Rahman ${ }^{1,2,3}$, Shamal Chandra Karmaker ${ }^{1,2,3}$, and Bidyut Baran Saha ${ }^{1,2, *}$ \\ ${ }^{1}$ International Institute for Carbon-Neutral Energy Research (WPI-I2CNER) \\ Kyushu University, 744 Motooka, Nishi-ku, Fukuoka-shi, Fukuoka 819-0395, Japan \\ ${ }^{2}$ Mechanical Engineering Department, Kyushu University, 744 Motooka, Nishi-ku, Fukuoka-shi, Fukuoka 819-0395, \\ Japan \\ ${ }^{3}$ Department of Statistics, University of Dhaka, Dhaka-1000, Bangladesh \\ *Corresponding author email: saha.baran.bidyut.213@m.kyushu-u.ac.jp
}

\begin{abstract}
This paper explores the impact of technological innovation on the quality of the environment during the period 1985-2014, using the environmental footprint (EF) as an environmental proxy for selected Asian nations. The findings show that technological innovation in relation to EF is negative and significant, indicating that a one-point increase in technological change leads to a decrease of 0.097 per cent in environmental deterioration. In addition, the granger causality test Dumitrescu-Hurlin (DH) indicated that technological advancement has a bi-directional relation with EF. Moreover, the study of variance decomposition showed that EF is strongly influenced by technological innovation. The policy implications of this study suggest that leveraging policy instruments and incentives should be pursued to improve technological innovation toward ensuring a sustainable environment.
\end{abstract}

Keywords: decomposition; ecological footprint; ganger causality; panel cointegration; technological innovation

\section{INTRODUCTION}

Human demand for natural resources is growing due to rapid economic growth and development that causes climate change, soil degradation, contamination of the environment, biodiversity loss and increased vulnerability to economic development [1,2]. These pressures on nature change the ecosystem by increasing environmental impact by depleting and extracting natural resources, emitting pollution, waste and moving organisms [3]. Ecological footprint (EF) is a comprehensive environmental assessment of the area of productive land and oceans needed to generate all the resources consumed by an individual and to absorb their waste [4,5]. The EF is an important instrument for tracking the impact of human demands on nature with respect to the five components of bio-capacity: cropland, fishing area, grazing land, forest and built-up land [6]. Human demand for natural resources has already surpassed its degree of productivity (biocapacity), i.e. the consumption of earth's resources exceeds its capacity to generate. Currently, it takes more than a year and a half to generate the resources that we use in one year [7]. The accumulative gap between EF and biocapacity reduces the earth's productivity, increases GHG and waste pollution, and hampers our ecosystem and biodiversity [8]. The technological innovation boosts the quality of the environment by minimizing energy usage and carbon emissions by adoption and transfer of environment friendly technologies and production process [9]. There is evidence that technological advancement reduces $\mathrm{CO}_{2}$ emissions and increases the environmental standards [10-12].

Studies about technologies and carbon emissions have grown over the past decade. The study focused at first on the effect of R\&D on carbon emissions and economic development in developing countries [10]. Researchers then examined at the connections between $R \& D$ investments in the energy sector and environmental quality in selected countries. Throughout the literature studies related to regulations, technologies and environment for development, carbon emissions and energy were developed [13-16]. There are also a variety of generic studies that discussed the environmental quality implications of technology and innovation [1719]. There is limited evidence of the use of innovation and research and development as a combination of technological effects in measuring their influence on environmental quality [20-24].

To the best of our knowledge there is a very little indication that technology-environmental link has been incorporated in a single analysis using EF as a measure of environmental quality. This paper thus contributes to this research gap by examining the impact of technological advancement on the environment using EF indicators.

This study is novel in the following three ways. First, it improves the environmental functionality of investigations by integrating technological innovation and four additional control variables into a common model for selected Asian countries. Second, the goal of this analysis is to investigate the technologyenvironmental connection from an Asian perspective and to use a comprehensive environmental footprint instead of carbon emission as a tool in a single study using panel data. Third, this study employs the Dumitrescu-Hurlin (DH) granger causality test and decomposition methods to define long-term causal connections and key explanatory variables contributions.

\section{DATA AND METHODOLOGY}


This paper uses annual data from selected Asian countries, including Bangladesh, Pakistan, India, Sri Lanka, Japan, Thailand, Indonesia, Malaysia, China and South Korea for the period 1985-2014 to examine the impact of technological advancement on environmental quality. We utilize the data collection approach outline in Saud et al. [3] and Destek \& Sarkodie [25], the data on EF indicator as a proxy of environmental quality (in global hectares per capita) has been extracted from the National Footprint Accounts (NFA) of the Global Footprint Network [26]. Data on the number of patent applications have been used as proxies for technological innovation. In addition, GDP per capita (in constant 2010 US\$), energy consumption (in $\mathrm{kg}$ of oil equivalent per capita), $\mathrm{CO}_{2}$ emissions (in metric ton per capita), and urban population (in percentage of total population) were obtained from the Word Development Indicator (WDI) databank [27]. The variables incorporated in this analysis are presented in Table 1. To address normality as well as control the possibility of heteroscedasticity, all variables are converted into the natural logarithm form.

Table 1 Variables, measures, and definition

\begin{tabular}{|c|c|c|c|}
\hline Variables & $\begin{array}{c}\text { Symbols } \\
\text { (source) }\end{array}$ & Measures & Time Period \\
\hline $\begin{array}{c}\text { Ecological } \\
\text { Footprint }\end{array}$ & $\begin{array}{c}\mathrm{EF} \\
(\mathrm{NFA})\end{array}$ & $\begin{array}{c}\text { In global } \\
\text { hectares/ } \\
\text { capita }\end{array}$ & $1985-2014$ \\
\hline $\begin{array}{l}\text { Technological } \\
\text { Innovation }\end{array}$ & $\begin{array}{c}\text { TI } \\
\text { (WDI) }\end{array}$ & $\begin{array}{l}\text { Number of } \\
\text { Patent } \\
\text { Application }\end{array}$ & $1985-2014$ \\
\hline GDP Per capita & $\begin{array}{l}\text { GDP } \\
\text { (WDI) }\end{array}$ & $\begin{array}{l}\text { In constant } \\
2010 \text { US\$ }\end{array}$ & $1985-2014$ \\
\hline $\mathrm{CO}_{2}$ Emission & $\begin{array}{c}\mathrm{C} \\
(\mathrm{WDI})\end{array}$ & $\begin{array}{l}\text { In metric } \\
\text { ton/capita }\end{array}$ & $1985-2014$ \\
\hline $\begin{array}{c}\text { Energy } \\
\text { consumption }\end{array}$ & $\begin{array}{c}\mathrm{EC} \\
(\mathrm{WDI})\end{array}$ & $\begin{array}{l}\text { In } \mathrm{kg} \text { of oil } \\
\text { equivalent/ } \\
\text { capita }\end{array}$ & $1985-2014$ \\
\hline $\begin{array}{c}\text { Urban } \\
\text { population }\end{array}$ & $\begin{array}{c}\text { UP } \\
\text { (WDI) }\end{array}$ & $\begin{array}{c}\text { In } \% \text { of total } \\
\text { population }\end{array}$ & $1985-2014$ \\
\hline
\end{tabular}

\subsection{Model specification}

Research that investigates specifically the connection between technological innovation and the EF is not common. By taking carbon emissions as the main environmental measure, most research has centered on the effect of technological change on environmental quality [20-24]. The following mathematical model is set out in Eq. (1) on the basis of the preceding literature examined in this study, enabling for the analysis of the impact of technological innovation on EF:

$$
E F=f(T I, G D P, C, E C, U P) \quad \text { Eq. (1) }
$$

Here, TI is the major independent variable. The variable GDP, C, EC and UP are taken as control variable. Following Saud et al. [3], Charfeddine \& Mrabet [28], Ganda [17] and Ahmed et al. [1], the econometric loglinear panel function of Eq. (1) be expressed as follows:

$$
\begin{aligned}
& \ln E F_{i t}=\alpha_{0}+\alpha_{1 i} \ln T I_{i t}+\alpha_{2 i} \ln G D P_{i t} \\
& +\alpha_{3 i} \ln C_{i t}+\alpha_{4 i} \ln E C_{i t}+\alpha_{5 i} \ln U P_{i t}+\varepsilon_{i t}
\end{aligned}
$$

Where $\alpha_{0}$ is the intercept and $\alpha_{1}, \alpha_{2}, \ldots \ldots, \alpha_{5}$ represents the slope coefficients, $i$ indicates the number of nations considered in this paper (i.e., 1,2,3 ....,N); $t$ represents time span (i.e., 1,2,3 ...,N) and $\varepsilon_{i t}$ is the random error term. The $\ln E F, \ln T I, \ln C, \ln E C$ and $\ln U P$ are the logarithm of the $E F, T I, C O_{2}$ emissions, $E C$ and $U P$, respectively. As $\ln E F$ represents the measure of environmental quality to support human demands, an increase in $E F$ indicates a commensurate raise in environmental degradation.

\subsection{Econometric methodology}

In this paper, panel unit root test [29], panel cointegration test [30-32], panel FMOLS estimates [30] Dumitrescu-Hurlin (D-H) causality approach [33] and variance decomposition method [34] have been employed to analyze the effect of technological innovation on environmental quality.

\section{RESULT AND DISCUSSION}

This section describes the empirical results of panel unit root tests, panel cointegration tests, fully modified ordinary least square (FMOLS) estimations, DumitrescuHurlin (DH) panel causality tests and variance decomposition analysis of the studied variables. A detailed discussion of the corresponding tests is

\begin{tabular}{|c|c|c|}
\hline \multirow[t]{2}{*}{ Variable } & \multicolumn{2}{|c|}{ LLC } \\
\hline & Level & 1st difference \\
\hline $\operatorname{lnEF}$ & $0.544[0.70]$ & $-9.884^{\mathrm{a}}[0.00]$ \\
\hline $\ln T I$ & $2.676[0.99]$ & $-15.248^{\mathrm{a}}[0.00]$ \\
\hline $\ln C$ & $0.479[0.68]$ & $-7.477^{\mathrm{a}}[0.00]$ \\
\hline $\operatorname{lnEC}$ & $10.656[1.00]$ & $-7.982^{\mathrm{a}}[0.00]$ \\
\hline $\operatorname{lnUP}$ & $1.743[0.959]$ & $-2.742^{\mathrm{a}}[0.003]$ \\
\hline \multirow[t]{3}{*}{$\operatorname{lnGDP}$} & $14.464[1.00]$ & $-3.723^{\mathrm{a}}[0.001]$ \\
\hline & \multicolumn{2}{|c|}{ IPS } \\
\hline & Level & 1st difference \\
\hline $\operatorname{lnEF}$ & $1.586[0.943]$ & $-11.740^{\mathrm{a}}[0.00]$ \\
\hline $\ln \mathrm{TI}$ & $-0.198[0.421]$ & $-17.504^{\mathrm{a}}[0.00]$ \\
\hline $\ln C$ & $0.244[0.596]$ & $-11.486^{\mathrm{a}}[0.00]$ \\
\hline $\operatorname{lnEC}$ & $0.301[0.618]$ & $-11.221^{\mathrm{a}}[0.00]$ \\
\hline $\operatorname{lnUP}$ & $0.239[0.594]$ & $0.529[0.701]$ \\
\hline $\operatorname{lnGDP}$ & $5.365[1.00]$ & $-7.161^{\mathrm{a}}[0.00]$ \\
\hline
\end{tabular}
presented below.

Table 2 Panel unit root test to identify stationary

Note: Number in third bracket indicates p-value; a, b and c indicate $1 \%, 5 \%$ and $10 \%$ level of significance, respectively.

The null hypothesis of the unit root test states that the variables are non-stationary. The LLC and IPS tests endorse that the null hypothesis is insignificant at level, but significant at first difference at $1 \%$ level of significance. Hence, according to both tests, all six variables are cointegrated in order one, i.e. I (1). In summary, it can be said that all studied variables adopted in Eq. (2) are non-stationary and the process is considered as $I$ (1). Hence, there is an evidence of cointegrated relationships among the variables studied in this analysis. In order to examine the cointegration relationship among the variables, seven panel cointegration tests are employed in this study and the results of cointegration are presented in

Table 3. The null hypothesis of cointegration test assumes that there is no cointegration in the panel data. The findings of cointegration test presented in

Table 3 confirm that the null hypothesis is rejected at the $1 \%$ significance level. Thus, the test results confirm the evidence of cointegration among the studied variables. 
Table 3 Results Panel cointegration tests

\begin{tabular}{cc}
\hline \hline Test & Statistic \\
\hline Panel PP (unweighted) & $-3.755^{\mathrm{a}}[0.0001]$ \\
Panel PP [weighted] & $-3.451^{\mathrm{a}}[0.0000]$ \\
Group PP & $-5.686^{\mathrm{a}}[0.0000]$ \\
Panel ADF [unweighted] & $-3.589^{\mathrm{a}}[0.0000]$ \\
Panel ADF [weighted] & $-4.511^{\mathrm{a}}[0.0000]$ \\
Group ADF & $-5.238^{\mathrm{a}}[0.0000]$ \\
Kao test stat & $-3.177^{\mathrm{a}}[0.0000]$ \\
\hline \hline
\end{tabular}

Note: Number in third bracket indicates p-value; $a, b$ and $\mathrm{c}$ indicate $1 \%$, $5 \%$ and $10 \%$ level of significance, respectively.

Following confirmation of cointegration among variables, the FMOLS method was used to determine the long-run coefficients of all the variables analyzed, and the results are shown in Table 4.

Table 4 Parameter estimation using FMOLS method

\begin{tabular}{llll}
\hline \hline Variable & Estimates & $\begin{array}{l}\text { Standard } \\
\text { error }\end{array}$ & p-value \\
\hline $\operatorname{lnTI}$ & -0.09729 & $0.0314 * * *$ & 0.0001 \\
$\ln \mathrm{GDP}$ & 0.28232 & $0.0765^{* * *}$ & 0.0000 \\
$\ln \mathrm{C}$ & 0.58574 & $0.1176^{* * *}$ & 0.0000 \\
$\operatorname{lnEC}$ & 0.21014 & 0.1146 & 0.4358 \\
$\ln \mathrm{UP}$ & -0.7270 & $0.1682^{* * *}$ & 0.0000 \\
\hline \hline
\end{tabular}

Note: Significant at $\left({ }^{*} 10 \%{ }^{* *} 5 \%,{ }^{* * *} 1 \%\right)$ level.

In this analysis the impact of technological innovation on $\mathrm{EF}$ is of primary interest. The estimated coefficient of technological innovation with respect to the EF is negative $(\alpha 1$ is $-0,09729)$ and statistically significant at a level of 1 percent, suggesting that a one-point growth in technological innovation leads to a decrease in environmental deterioration of 0.097 percent. Innovation and technology investment may affect environmental quality through reducing emission levels [17]. Technological innovation eliminates the exploitation of natural resources as inputs in production lines, thereby reducing negative environmental impacts [35]. Green investment for technological diffusion and the introduction of eco-friendly technologies can exert a substantial effect on the environment [3]. Our results also show that GDP, $\mathrm{CO}_{2}$ emissions and urbanization have a statistically significant impact on EF at the $1 \%$ significance level, however, energy usage has a positive yet insignificant consequence on environmental quality. The FMOLS estimation results obtained in this paper confirm that technological innovation reduces environmental degradation. The long-run relationship among the studied variables explored in this paper are summarized in Figure 1.

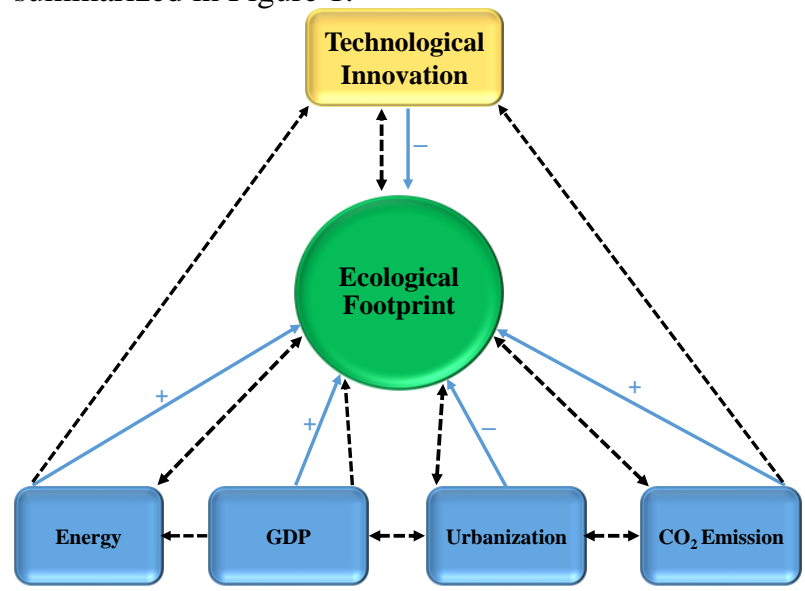

Figure $1 \mathrm{DH}$ causality relationship and long-run estimation links among modeled variables, where, $(+)$ and (-) indicates positive and negative long-run panel relationship; $(-\boldsymbol{-} \rightarrow)$ indicates unidirectional and $(\leftarrow-\rightarrow)$ indicates bidirectional DH causality.

Table 5 Dumitrescu-Hurlin (DH) panel causality test results

\begin{tabular}{|c|c|c|c|c|c|c|}
\hline Variables & lnEF & $\ln \mathrm{lnI}$ & lnGDP & $\overline{l n} \mathrm{ln}$ & $\overline{l n E C}$ & lnUP \\
\hline $\operatorname{lnEF}$ & & $\begin{array}{l}3.964^{b} \\
{[2.327]} \\
0.019\end{array}$ & $\begin{array}{l}2.258 \\
{[0.089]} \\
0.928\end{array}$ & $\begin{array}{l}4.724^{\mathrm{a}} \\
{[3.324]} \\
0.000\end{array}$ & $\begin{array}{l}3.723^{b} \\
{[2.011]} \\
0.044\end{array}$ & $\begin{array}{c}4.234^{\mathrm{a}} \\
{[2.682]} \\
0.007\end{array}$ \\
\hline $\ln T I$ & $\begin{array}{l}4.244^{\mathrm{a}} \\
{[2.695]} \\
0.007\end{array}$ & & $\begin{array}{l}0.997 \\
{[-1.56]} \\
0.117\end{array}$ & $\begin{array}{l}3.321 \\
{[1.484]} \\
0.137\end{array}$ & $\begin{array}{l}5.100^{\mathrm{a}} \\
{[3.818]} \\
0.000\end{array}$ & $\begin{array}{l}6.260^{\mathrm{a}} \\
{[5.340]} \\
0.000\end{array}$ \\
\hline $\operatorname{lnGDP}$ & $\begin{array}{l}6.206^{\mathrm{a}} \\
{[5.270]} \\
0.000\end{array}$ & $\begin{array}{l}4.968^{\mathrm{a}} \\
{[3.645]} \\
0.000\end{array}$ & & $\begin{array}{l}4.270^{\mathrm{a}} \\
{[2.728]} \\
0.006\end{array}$ & $\begin{array}{l}5.381^{\mathrm{a}} \\
{[4.187]} \\
0.000\end{array}$ & $\begin{array}{l}4.874^{a} \\
{[3.522]} \\
0.000\end{array}$ \\
\hline $\ln C$ & $\begin{array}{l}5.620^{\mathrm{a}} \\
{[4.500]} \\
0.000\end{array}$ & $\begin{array}{l}4.339^{\mathrm{a}} \\
{[2.819]} \\
0.004\end{array}$ & $\begin{array}{l}1.788 \\
{[-0.52]} \\
0.597\end{array}$ & & $\begin{array}{l}3.598^{\mathrm{b}} \\
{[1.847]} \\
0.047\end{array}$ & $\begin{array}{l}4.159^{a} \\
{[2.583]} \\
0.009\end{array}$ \\
\hline $\operatorname{lnEC}$ & $\begin{array}{l}4.482^{\mathrm{a}} \\
{[3.007]} \\
0.003\end{array}$ & $\begin{array}{l}5.550^{\mathrm{a}} \\
{[4.409]} \\
0.000\end{array}$ & $\begin{array}{l}2.3482 \\
{[0.206]} \\
0.836\end{array}$ & $\begin{array}{l}5.321^{\mathrm{a}} \\
{[4.108]} \\
0.000\end{array}$ & & $\begin{array}{l}5.107^{\mathrm{a}} \\
{[3.827]} \\
0.000\end{array}$ \\
\hline $\operatorname{lnUP}$ & $\begin{array}{l}5.682^{\mathrm{a}} \\
{[4.581]} \\
0.000\end{array}$ & $\begin{array}{l}5.670^{\mathrm{a}} \\
{[4.566]} \\
0.000\end{array}$ & $\begin{array}{l}6.383^{\mathrm{a}} \\
{[5.502]} \\
0.000\end{array}$ & $\begin{array}{l}5.309^{\mathrm{a}} \\
{[4.092]} \\
0.000\end{array}$ & $\begin{array}{l}6.230^{\mathrm{a}} \\
{[5.301]} \\
0.000\end{array}$ & \\
\hline
\end{tabular}

Note: $\mathrm{H}_{0}$ : No causality; Top values indicate $\mathrm{W}$-stat; [ ] values indicate $\mathrm{Z}$-stat; a indicates $1 \%$ and $\mathrm{b}$ indicates $5 \%$ level of significance.

The results disclose Granger causality from technological innovation (TI) to ecological footprint (EF) and urbanization (UP). The technological innovation (TI), carbon emissions (C), energy consumption (EC) and urbanization (UP) have a significant, bi-directional causal relationship with EF. The bi-directional relationship between $\mathrm{EC}$ and $\mathrm{EF}$ concludes that EC impacts $\mathrm{EF}$, triggering in environmental degradation. This high environmental deterioration motivates the policymakers to limit the use of energy which results in a feedback effect. There is evidence of significant bidirectional Granger causalities between $\mathrm{EC}$ and $\mathrm{CO}_{2}$ and UP and $\mathrm{CO}_{2}$. A statistically significant unidirectional causality running from GDP to $\mathrm{CO}_{2}$. The causal relationships among modeled variables expressed in Table 5 were graphically summarized in Figure 1.

The findings of variance decomposition analysis based on Eq. (2) using a vector error correction model (VECM) are displayed in Table 6 . This table reveals that approximately $66 \%$ of EF is attributable to endogenous shocks while the impact of TI, GDP, $\mathrm{CO}_{2}, \mathrm{EC}$ and UP on $\mathrm{EF}$ in the long run are about $9 \%, 2.4 \%, 5.30 \%, 15.15 \%$ and $2 \%$, respectively. In summary, it can be said that technological innovation has a substantial effect on ecological footprints.

Table 6 Variance decomposition analysis of ecological footprint (EF).

\begin{tabular}{ccccccc}
\hline \hline Period & EF & TI & GDP & $\mathrm{CO}_{2}$ & CO2 & UP \\
\hline 1 & 100.00 & 0.00 & 0.00 & 0.00 & 0.00 & 0.00 \\
2 & 97.98 & 0.00 & 0.14 & 0.42 & 0.42 & 0.26 \\
3 & 93.56 & 0.39 & 1.30 & 1.90 & 1.90 & 0.24 \\
4 & 90.91 & 0.59 & 1.48 & 3.71 & 3.71 & 0.24 \\
5 & 84.18 & 1.39 & 1.18 & 7.98 & 7.98 & 0.19 \\
6 & 80.93 & 2.31 & 1.09 & 7.52 & 7.52 & 0.15 \\
7 & 76.35 & 3.06 & 1.16 & 7.30 & 7.30 & 0.73 \\
8 & 70.22 & 6.74 & 1.42 & 5.76 & 5.76 & 1.26 \\
\hline \hline
\end{tabular}




\begin{tabular}{llllccc}
\hline 9 & 66.76 & 8.54 & 2.00 & 5.14 & 5.14 & 2.14 \\
10 & 65.51 & 8.88 & 2.44 & 5.30 & 15.15 & 2.00 \\
\hline \hline
\end{tabular}

Figure 2 shows the country-wise variance decomposition analysis (ten-year horizon) based on a vector error correction model (VECM). The long-term projected effect of technological innovation on ecological footprints in the long-term were discovered to be the highest in China and India, respectively.

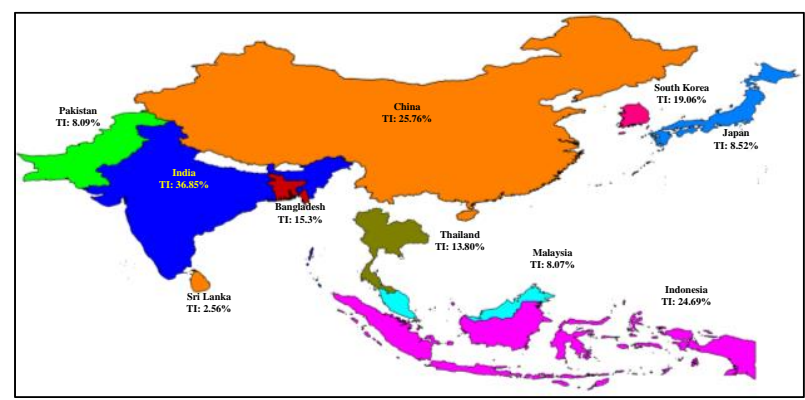

Figure 2 Country-wise long-run contribution of TI on Ecological footprint (EF).

The ultimate aim of this paper was the exploration of the effects of technological advancement on environmental quality using a panel cointegration framework. This method has the benefit of enabling significant clarifying ability through its statistical analysis and power that have been generally ignored in previous literature. The results confirm evidence that technological innovation significantly reduces $\mathrm{EF}$ which implies improving the quality of the environment. The direction of causality was also investigated applying the DH panel causality test. This result identifies short-run causality running from financial development and technological innovation to EF. Additionally, the variance decomposition analysis shows that technological innovation stimulates EF to a greater degree than financial development.

\section{CONCLUSION AND POLICY FORMULATION}

This paper analyzed the effect of technological advancement on environmental quality considering EF as environmental proxy in selected Asian countries over the period 1985-2014. The empirical results specify that the technological innovation is reducing $\mathrm{EF}$ and is not harming the environment. Overall, technological development in Asian countries currently affects EF. Technological innovation plays a major role in environmental development by introducing energyefficient production technology and operational efficiency in production processes. In term of causality analysis, DH Granger causality tests reveals the presence of long-run relationship between technological innovation, EF, energy use and urbanization. In the short term, we found strong evidence for bidirectional causality between the EF, technological innovation, and energy use. We have found a causal unidirectional relationship that runs from technological innovation to $\mathrm{EF}$, from urbanization to energy usage, and from GDP to energy usage.

The findings of this paper underpin policy implications which can enable the analyzed nations to regulate the adverse consequences of environmental hazards. Based on our findings, we recommend a range of financial, technological, and energy policies that can support to significantly advance the quality of the environment. Governments could improve EF outcomes by formulating techno-environmental policies in line with these findings. This is imperative given the consequences of related issues such as aging populations, new technologies and digitization, climate change and increasing consumer demand, and the adoption of new sets of technical skills and green performance standards required to build a green economy. As such, innovation and technological investment policies should focus on 'green' strategies. Greening technological policies will ensure that both environmental and social justice are addressed while promoting sustainable economic growth Green policy integration would promote the development of more technological innovation capable of managing associated risks and the uncertainties associated with emerging innovation and technology development. To ensure energy efficiency and reduce carbon emissions, renewable energy technology, key material technology, and low carbon technologies should be developed.

Our findings also point to the effect of urbanization and energy use on the environment for which energy conservation strategies and numerous environmental awareness initiatives need to be launched, specific to the urban region. Energy efficient technology for industrial and household use as well as green transport through the introduction of smart technology should be promoted for sustainable environmental development. Policies should also be introduced to promote green technologies to curb pollution from industrial development through financial and economic growth. There should be support and motivation for national and international environmental institutions to target different businesses for promoting energy efficiency and efficient use of ecological resources. Government and private sectors should participate in technological innovation in the energy sectors which will reduce the detrimental impact of energy consumption on EF.

Lastly, from a policy perspective, our findings have many important policy implications which contribute to the ecological economy by illustrating the implementation pathways for achieving several Sustainable Development Goals and how technological innovation can serve as a catalyst in this implementation process. The major finding, however, identifies the fact that pooling several countries with different economic characteristics in just one group can lead to hiding the true relationship between technological innovation and environmental degradation. This outcome can contribute to inappropriate policy design and implementation. Consequently, specific, and oriented national group policies are strongly recommended. technological innovation is strongly affected by government policies, and the effect of technological innovation on EF can also be recognized under government environmental regulatory constraints. Furthermore, it is important to note that robust policy design calls for data availability, one of the major issues encountered by several researchers in the context of Asian countries. Indeed, one limitation of this study was the challenge of data availability for a broad range of nations, limiting the scope of our investigations. 


\section{REFERENCES}

[1] Z. Ahmed, M.W. Zafar, S. Ali, Danish, Linking urbanization, human capital, and the ecological footprint in G7 countries: An empirical analysis, Sustain. Cities Soc. 55 (2020) 102064. https://doi.org/10.1016/j.scs.2020.102064.

[2] J. Lan, A. Malik, M. Lenzen, D. McBain, K. Kanemoto, A structural decomposition analysis of global energy footprints, Appl. Energy. 163 (2016) 436-451. https://doi.org/10.1016/j.apenergy.2015.10.178.

[3] S. Saud, S. Chen, A. Haseeb, Sumayya, The role of financial development and globalization in the environment: Accounting ecological footprint indicators for selected one-belt-oneroad initiative countries, J. Clean. Prod. 250 (2020) 119518. https://doi.org/10.1016/j.jclepro.2019.119518.

[4] A. Galli, J. Kitzes, P. Wermer, M. Wackernagel, V. Niccolucci, E. Tiezzi, An exploration of the mathematics behind the ecological footprint, Int. J. Ecodynamics. 2 (2007) 250-257. https://doi.org/10.2495/ECO-V2-N4-250-257.

[5] M. Wackernagel, N.B. Schulz, D. Deumling, A.C. Linares, M. Jenkins, V. Kapos, C. Monfreda, J. Loh, N. Myers, R. Norgaard, J. Randers, Tracking the ecological overshoot of the human economy, Proc. Natl. Acad. Sci. U. S. A. 99 (2002) 9266-9271. https://doi.org/10.1073/pnas.142033699.

[6] B. Ewing, D. Moore, S.H. Goldfinger, A. Oursler, A. Reed, M. Wackernagel, Ecological Footprint Atlas 2010, Glob. Footpr. Netw. (2010) 1-111.

[7] Z. Ahmed, Z. Wang, Investigating the impact of human capital on the ecological footprint in India: An empirical analysis, Environ. Sci. Pollut. Res. 26 (2019) 26782-26796. https://doi.org/10.1007/s11356-019-05911-7.

[8] A. Rashid, A. Irum, I.A. Malik, A. Ashraf, L. Rongqiong, G. Liu, H. Ullah, M.U. Ali, B. Yousaf, Ecological footprint of Rawalpindi; Pakistan's first footprint analysis from urbanization perspective, J. Clean. Prod. 170 (2018) 362-368. https://doi.org/10.1016/j.jclepro.2017.09.186.

[9] P. Pazienza, The relationship between $\mathrm{CO} 2$ and Foreign Direct Investment in the agriculture and fishing sector of OECD countries: Evidence and policy considerations, Intellect. Econ. 9 (2015) 55-66.

https://doi.org/10.1016/j.intele.2015.08.001.

[10] K. Fisher-Vanden, M.S. Ho, Technology, development, and the environment, J. Environ. Econ. Manage. 59 (2010) 94-108. https://doi.org/10.1016/j.jeem.2009.08.002.

[11] N. Zhou, M.D. Levine, L. Price, Overview of current energy-efficiency policies in China, Energy Policy. 38 (2010) 6439-6452. https://doi.org/10.1016/j.enpol.2009.08.015.

[12] E. Ali, Modeling and Optimization of Biomass Supply Chain for Energy, Chemicals and Materials Productions by, (2016) 1-153.

[13] N.S. Lewis, Aspects of science and technology in support of legal and policy frameworks associated with a global carbon emissionscontrol regime, Energy Environ. Sci. 9 (2016) 2172-2176. https://doi.org/10.1039/c6ee00272b.

[14] X. Pan, B. Ai, C. Li, X. Pan, Y. Yan, Dynamic relationship among environmental regulation, technological innovation and energy efficiency based on large scale provincial panel data in China, Technol. Forecast. Soc. Change. 144 (2019) 428-435.

https://doi.org/10.1016/j.techfore.2017.12.012.

[15] H. Wang, M. Wang, Effects of technological innovation on energy efficiency in China:

Evidence from dynamic panel of 284 cities, Sci. Total Environ. 709 (2020) 136172. https://doi.org/10.1016/j.scitotenv.2019.136172.

[16] M. Hassan, T.H. Rupam, W. Bin Habib, Green Building: An Emerging Technology for the Energy Crisis of Bangladesh, Proc. Int. Exch. Innov. Conf. Eng. Sci. (2016) 1.

[17] F. Ganda, The impact of innovation and technology investments on carbon emissions in selected organisation for economic Cooperation and development countries, J. Clean. Prod. 217 (2019) 469-483.

https://doi.org/10.1016/j.jclepro.2019.01.235.

[18] G.J. de Vries, B. Ferrarini, What Accounts for the Growth of Carbon Dioxide Emissions in Advanced and Emerging Economies? The Role of Consumption, Technology and Global Supply Chain Participation, Ecol. Econ. 132 (2017) 213-223.

https://doi.org/10.1016/j.ecolecon.2016.11.001.

[19] M. Irandoust, The renewable energy-growth nexus with carbon emissions and technological innovation: Evidence from the Nordic countries, Ecol. Indic. 69 (2016) 118-125.

https://doi.org/10.1016/j.ecolind.2016.03.051.

[20] N. Apergis, S. Eleftheriou, J.E. Payne, The relationship between international financial reporting standards, carbon emissions, and R\&D expenditures: Evidence from European manufacturing firms, Ecol. Econ. 88 (2013) 5766.

https://doi.org/10.1016/j.ecolecon.2012.12.024.

[21] A. Álvarez-Herránz, D. Balsalobre, J.M.

Cantos, M. Shahbaz, Energy Innovations-GHG

Emissions Nexus: Fresh Empirical Evidence from OECD Countries, Energy Policy. 101 (2017) 90-100.

https://doi.org/10.1016/j.enpol.2016.11.030.

[22] S. Awaworyi Churchill, J. Inekwe, R. Smyth, X. Zhang, R\&D intensity and carbon emissions in the G7: 1870-2014, Energy Econ. 80 (2019) 30-37.

https://doi.org/10.1016/j.eneco.2018.12.020.

[23] A. Sinha, T. Sengupta, R. Alvarado, Interplay between technological innovation and environmental quality: Formulating the SDG policies for next 11 economies, J. Clean. Prod. 242 (2020) 118549.

https://doi.org/10.1016/j.jclepro.2019.118549.

[24] H. Saleem, M.B. Khan, M.S. Shabbir, The role of financial development, energy demand, and 
technological change in environmental sustainability agenda: evidence from selected Asian countries, Environ. Sci. Pollut. Res. 27 (2020) 5266-5280. https://doi.org/10.1007/s11356-019-07039-0.

[25] M.A. Destek, S.A. Sarkodie, Investigation of environmental Kuznets curve for ecological footprint: The role of energy and financial development, Sci. Total Environ. 650 (2019) 2483-2489.

https://doi.org/10.1016/j.scitotenv.2018.10.017.

[26] Global Footprint Network; 2020, 2020. (n.d.). https://data.footprintnetwork.org/?_ga=2.19250 877.483299547.1597582475$1928321592.1597582475 \# /$.

[27] World Bank, (2020). https://databank.worldbank.org/source/worlddevelopment-indicators.

[28] L. Charfeddine, Z. Mrabet, The impact of economic development and social-political factors on ecological footprint: A panel data analysis for 15 MENA countries, Renew. Sustain. Energy Rev. 76 (2017) 138-154. https://doi.org/10.1016/j.rser.2017.03.031.

[29] A. Levin, C.F. Lin, C.S.J. Chu, Unit root tests in panel data: Asymptotic and finite-sample properties, J. Econom. 108 (2002) 1-24. https://doi.org/10.1016/S0304-4076(01)000987.

[30] P. Pedroni, Fully Modified OlS for Heterogeneous Cointegrated Panels., Nonstationary Panels, Panel Cointegration Dyn. Panels,. 15 (2000) 93-130.

[31] P. Pedroni, Critical Values for Cointegration Tests in Heterogeneous Panels with Multiple Regressors, Oxf. Bull. Econ. Stat. 61 (1999) 653-670. https://doi.org/10.1111/14680084.61.s1.14.

[32] C. Kao, Spurious regression and residual-based tests for cointegration in panel data, J. Econom. 90 (1999) 1-44. https://doi.org/10.1016/S03044076(98)00023-2.

[33] E.I. Dumitrescu, C. Hurlin, Testing for Granger non-causality in heterogeneous panels, Econ. Model. 29 (2012) 1450-1460. https://doi.org/10.1016/j.econmod.2012.02.014.

[34] H. Lutkepohl, New Introduction to Multiple Time Series Analysis, New Introd. to Mult. Time Ser. Anal. (2005). https://doi.org/10.1007/3-540-27752-8.

[35] S. Borghesi, A. Vercelli, Sustainable globalisation, 44 (2003) 77-89. 